\title{
SURFACE CHARACTERISTICS OF INVAR ALLOY ACCORDING TO MICRO-PULSE ELECTROCHEMICAL MACHINING
}

\author{
KARAKTERISTIKE POVRŠINE INVAR ZLITINE GLEDE NA \\ MIKROPULZNO ELEKTROKEMIČNO OBDELAVO
}

\author{
Seong-Hyun Kim, Seung-Geon Choi, Woong-Kirl Choi, Eun-Sang Lee \\ Inha University, Department of Mechanical Engineering, 253 Yonghyun-Dong, Nam-Gu, Incheon 402-751, Republic of Korea \\ kimseonghyun@inha.edu, leees@inha.ac.kr
}

Prejem rokopisa - received: 2016-07-15; sprejem za objavo - accepted for publication: 2017-01-24

doi: $10.17222 /$ mit.2016.187

\begin{abstract}
Invar is a $36 \%$ nickel iron alloy that has a low thermal expansion, compared to other metals and alloys, at temperatures ranging from room temperature up to approximately $230^{\circ} \mathrm{C}$. Invar alloy is ductile, easily weldable and its machinability is similar to that of austenitic stainless steel. Due to the low thermal expansion of Invar, it is used for shadow masks for display devices such as UHDTV - organic light-emitting diode. In this study, micro-pulse electrochemical machining (MPECM), which is a non-contact ultra-precision machining method, was developed to manufacture Invar sheets; optimum parameters of MPECM were defined and the basic MPECM experiments were carried out on an Invar sheet. The optimum parameters were determined with pulse-on time and duty-ratio analysis. The experimental results show that MPECM is hard to control. Therefore, using ultrashort charging times and very high pulses, it is possible to achieve a successful anodic dissolution at a very small electrode gap. Hence, a longer pulse-on time and a small electrode gap may provide the scope for further improvement of the machining accuracy by controlling the localization effect. Furthermore, the machining depth and MPECM efficiency were investigated with respect to various parameters and pulse-on time, considering different duty-ratio conditions.
\end{abstract}

Keywords: Invar alloy, electrochemical machining, surface characteristics

Invar je $36 \%$ zlitina niklja in železa, ki ima v primerjavi z vsemi kovinami in zlitinami, nizek koeficient toplotnega raztezka v območju sobne temperature pa do okoli $230^{\circ} \mathrm{C}$. Invar zlitina je duktilna, primerna za enostavno varjenje in njena obdelovalnost je podobna avstenitnemu nerjavnemu jeklu. Zaradi nizkega koeficienta termičnega raztezka, se zlitina Invar uporablja v maskah za senčenje displejev v OLED-UHD TV (angl.: Organic Light Emitting Diode - Ultra High Definition TeleVision) napravah. V tej študiji je bila razvita metoda mikropulzne elektrokemične obdelave kovin (angl. MPECM), ki je brezkontaktna ultraprecizna tehnologija mehanske obdelave. Izvedeni so bili osnovni poskusi na zlitini Invar. Določeni so bili optimalni parametri postopka. Eksperimentalni rezultati kažejo, da je obdelovalnost z MPECM težko nadzorovati. Izjemno kratki časi, z zelo visokimi napetostnimi impulzi, omogočajo nastanek pogojev za uspešno anodno raztapljanje kovine pri zelo majhni reži elektrode. Zato se pri zelo visokem številov impulzov in manjšem razmiku elektrod, lahko zagotovi nadaljnje izboljšanje točnosti obdelave z MPECM. Nadalje je bila raziskana obdelovalna globina in obdelovalnost Z MPECM pri različnih procesnih parametrih (napetost-čas-storilnost).

Ključne besede: Invar zlitina, elektrokemična obdelava, površinske karakteristike

\section{INTRODUCTION}

Invar is an alloy of $64 \%$ iron and $36 \%$ nickel. Its coefficient of expansion is very low, namely $1.8 \times 10^{-6}$ $\mathrm{cm} /{ }^{\circ} \mathrm{C}$, at temperatures ranging from a cryogenic temperature of $-196{ }^{\circ} \mathrm{C}$ to a Currie temperature of $260{ }^{\circ} \mathrm{C}$. This value is 10 times lower than that of stainless steel and 100 times lower than that of iron, which makes Invar appropriate for applications in various fields of study. Invar is used in ultra-high-definition televisions, display shadow masks, organic light-emitting diodes, controllers for quality, colors, and for the definition of images in mobile devices and other instruments that require precise measurements. ${ }^{1-3}$ Invar is also used in electron-gun electrodes (devices that eject an electron beam into the hole in a shadow mask), lead frames (to protect semiconductor chips from external damage) and other industrial devices.

Invar is currently manufactured with mechanical processes or electroforming; other methodologies have also been suggested. To maintain the specific characteristics of Invar alloys, advanced machining methods are being studied, such as laser machining, supersonic-wave machining, micro-end mills/drilling, electropolishing and electrochemical machining. ${ }^{4-6}$ Moreover, the effects of hydrodynamics and temperature on the electrode position of $\mathrm{Fe}-\mathrm{Ni}$ (Invar) alloys has been investigated with DC, pulse, and pulse-reverse electrodeposition techniques. ${ }^{7,8}$ MPECM has seen a resurgence of industrial interest within the last decade, due to its many advantages, such as no tool wear, stress-free and smooth surfaces, and the ability to machine complexly shaped products made from different materials, regardless of their hardness and high strength, high tension, or whether they are heat-resistant materials..$^{9}$ In this study, the possibility of pulse electrochemical machining is investigated by analyzing the machinability characteristics of processed Invar prior to pulse electrochemical machining. 


\section{EXPERIMENTAL PART}

\subsection{Theory of the MPECM system}

Figure 1 shows a schematic diagram of the combined electrochemical process and the MPECM set-up with a previously developed microprobe. A pulsed voltage from a high-voltage pulse generator (Hewlett-Packard HP8116A) is applied to the gap between the anode and cathode, and the electrolyte solution is supplied through a hole in the cathode or an external electrolyte supplier. This homogenizes the electrochemical reaction and removes the gas and heat generated. The anode is the Invar alloy with a thickness of $30 \mu \mathrm{m}$ and the cathode is stainless steel with a 1-mm diameter.

The fully programmable $50 \mathrm{MHz}$ pulse generator has a variable pulse width (10 $\mathrm{ns} \mathrm{min})$ and the maximum output amplitude of the maximum voltage of $32 \mathrm{~V}$ p-p (in an open circuit). The high-speed data-acquisition system was provided by a TDS 2002C digital oscilloscope (Tektronix) with a bandwidth of $200 \mathrm{MHz}$ and a sampling rate of $500 \mathrm{MS} / \mathrm{s}$. Typical experimental conditions are shown in Table $\mathbf{1}$.

Table 1: Experimental conditions

\begin{tabular}{|l|l|}
\hline \multicolumn{1}{|c|}{ Parameter } & \multicolumn{1}{c|}{ Value } \\
\hline $\begin{array}{l}\text { Pulse generator } \\
\text { spec. }\end{array}$ & $\begin{array}{l}\text { HP8116A (Hewlett-Packard), 50MHz, } \\
\text { 32 V p-p, various (10 ns) pulse widths }\end{array}$ \\
\hline Workpiece (anode) & $\begin{array}{l}\text { Invar (Fe 64 \%, Ni 36 \%) 30- } \mu \mathrm{m} \\
\text { thickness }\end{array}$ \\
\hline Electrode (cathode) & $\begin{array}{l}\text { Stainless steel 304 ( } \varnothing \text { 1 mm) } \\
\text { Non-insulation, Insulation }\end{array}$ \\
\hline Digital oscilloscope & Tektronix TDS 2002C \\
\hline MPECM time & $\begin{array}{l}\text { 40 min (pulse-on time: 500 ns-2 } \mu \text { s, } \\
\text { Duty factor: 33-66 \%) }\end{array}$ \\
\hline Applied voltage (V) & 16 \\
\hline Electrode gap ( $\mu \mathrm{m})$ & 50 \\
\hline Electrolyte & $\begin{array}{l}\text { Sodium nitrite + sodium tartrate + DI } \\
\text { water }\end{array}$ \\
\hline Measurement & $\begin{array}{l}\text { Optical microscopic analysis, Scanning } \\
\text { electron microscopy (SEM), } \\
\text { Non-contact 3D profile }\end{array}$ \\
\hline
\end{tabular}

\subsection{Electrode type}

The concentration of the current at the edges and irregular parts of an electrode can lead to localized sedimentation on the anode surface. A specially designed electrode is recommended for electrochemical micromachining to control the dimensions of the Invar surface. Figure 2 compares the surfaces that were electrochemically micro-machined using two different electrodes. Electrode 1, with the traditional design, had a concentrated current at the edge, which is marked as a 2 . Electrode 2 has a non-conducting part that is marked as a 3. The current distribution for electrode 2 is uniform on the surface, which is marked as a 4 . Localized sedimentation was identified on the anode workpiece surface in the shape profile created by electrode 1 , but none was

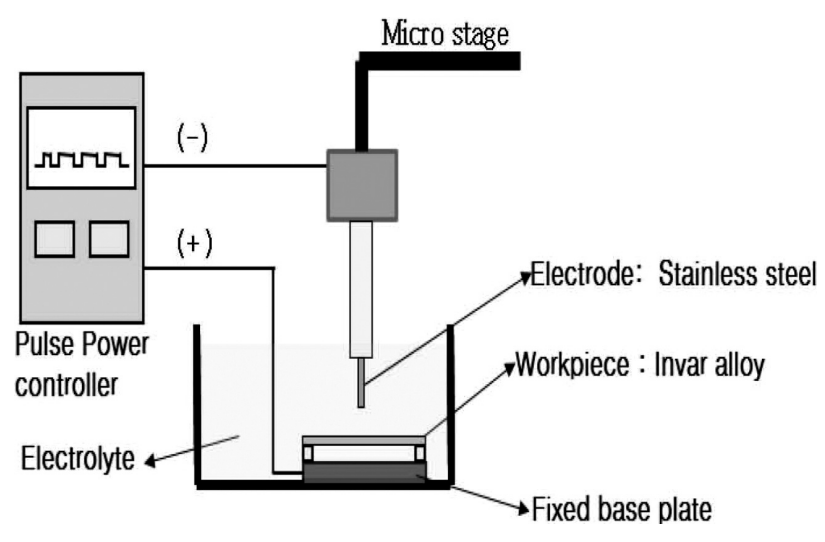

Figure 1: Micro-pulse electrochemical machining system

identified for electrode 2 . This results from non-conducting part 3 on the side of the electrode. The cathode design should be taken into account to precisely control the shape and prevent sedimentation.

When the electrodes are far apart, the voltage flows in the regions other than the processed area, even when no machining is intended. To reduce the unwanted voltage flowing in these regions, an electrode that is coated on the top can be used as the tool. To minimize this voltage and observe the behavior of the machining current, the sides of the tool need to be completely insulated.

\section{RESULTS AND DISCUSSION}

\subsection{Machining characteristics versus the pulse-on time using a non-insulated electrode}

The machining characteristics were studied using a voltage of $16 \mathrm{~V}$, a gap of $50 \mu \mathrm{m}$ a pulse-off time of $1 \mu \mathrm{s}$ and a machining time of $40 \mathrm{~min}$. An insulated electrode was used, and the pulse-on time was changed from 500 ns to $2 \mu \mathrm{s}$. Figure 3 shows that the machining radius was larger as the pulse-on time increased. The processed radius was $559.04 \mu \mathrm{m}$ at the pulse-on time of $500 \mathrm{~ns}$, $620.76 \mu \mathrm{m}$ at $600 \mathrm{~ns}, 675.21 \mu \mathrm{m}$ at $800 \mathrm{~ns}, 689.73 \mu \mathrm{m}$ at $1 \mu \mathrm{s}, 693.36 \mu \mathrm{m}$ at $1.5 \mu \mathrm{s}$, and $715.14 \mu \mathrm{m}$ at $2 \mu \mathrm{s}$. When the pulse-on time was $1 \mu$ s or higher, the machining radius drastically increased. Figure 4 shows the results after the machining with respect to the pulse-on time.

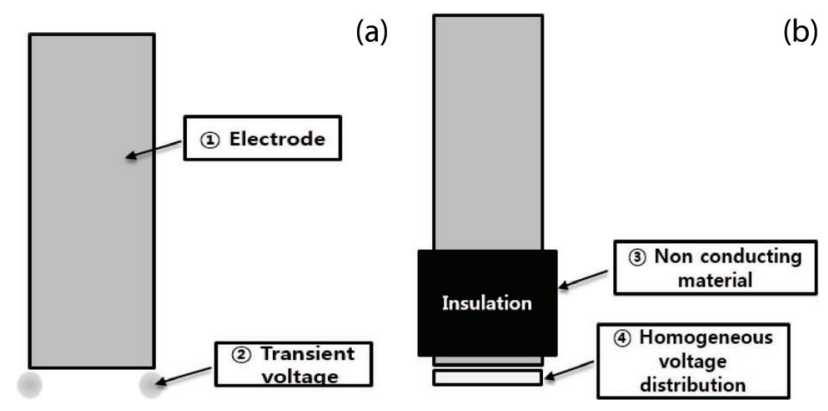

Figure 2: Comparison between two different electrodes 


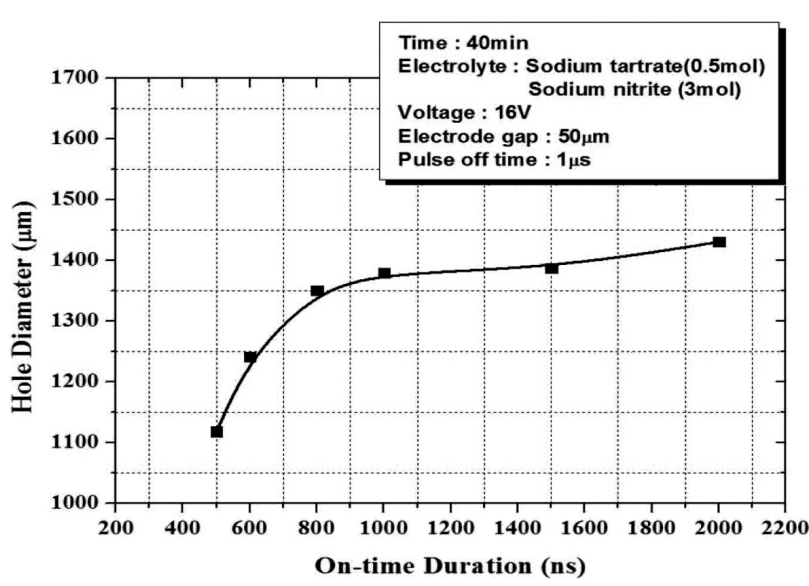

Figure 3: Increase of hole-diameter size versus pulse-on time

When the pulse-on time was $500-800 \mathrm{~ns}$, the machinability declined due to a low current density, but at 1-2 $\mu$ s, the machinability improved due to a high current density. The precision and the resulting image became better and better.

\subsection{Machining characteristics versus the pulse-on time using an insulated electrode}

The machining characteristics were also examined using an insulated electrode, with the other conditions

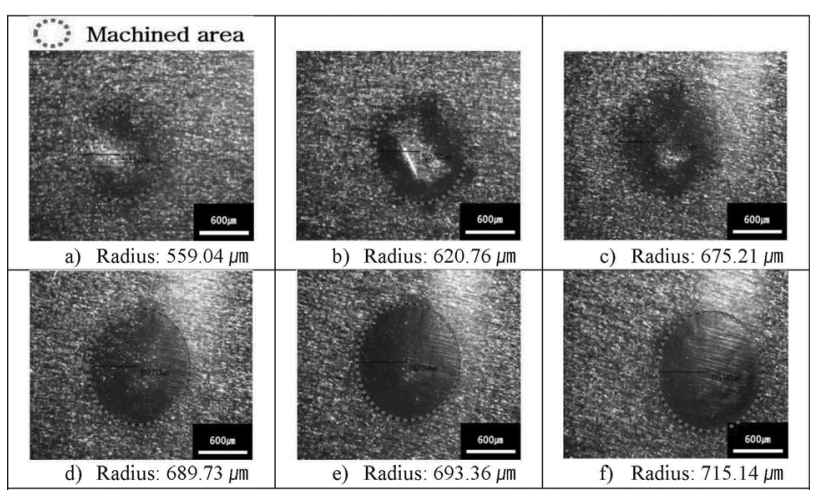

Figure 4: Crater-shape patterns with pulse-on time / duty factor and non-insulated electrode: a) $500 \mathrm{~ns} / 33 \%$, b) $600 \mathrm{~ns} / 37 \%$, c) $800 \mathrm{~ns} /$ $40 \%$, d) $1 \mu \mathrm{s} / 50 \%$, e) $1.5 \mu \mathrm{s} / 60 \%$, f) $2 \mu \mathrm{s} / 66 \%$

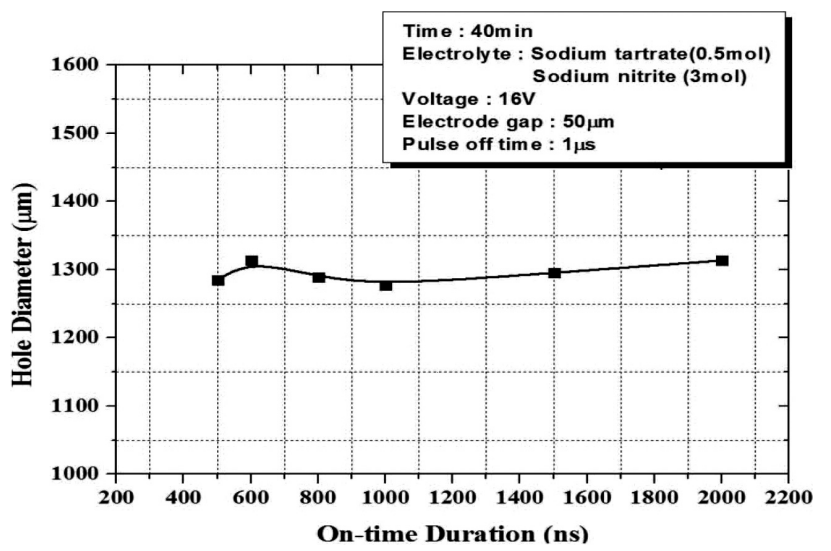

Figure 5: Increase of hole-diameter size versus pulse-on time

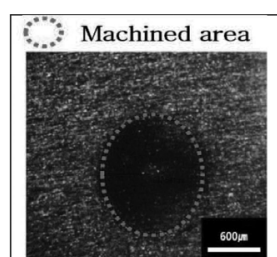

a) Radius: $642.54 \mu \mathrm{m}$

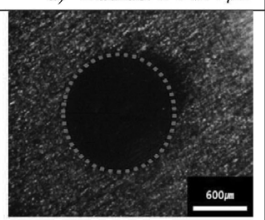

d) Radius: $638.72 \mu \mathrm{m}$

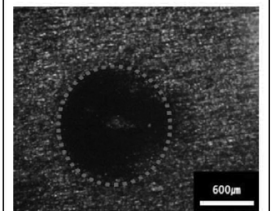

b) Radius: $656.81 \mu \mathrm{m}$

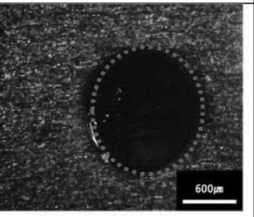

e) Radius: $647.77 \mu \mathrm{m}$

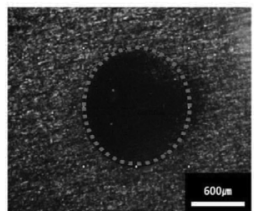

c) Radius: $644.76 \mu \mathrm{m}$

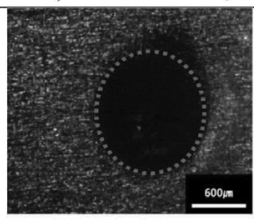

f) Radius: $656.81 \mu \mathrm{m}$

Figure 6: Crater-shape patterns with pulse-on time / duty factor and insulated electrode: a) $500 \mathrm{~ns} / 33 \%$, b) $600 \mathrm{~ns} / 37 \%$, c) $800 \mathrm{~ns} / 44$ $\%$, d) $1 \mu \mathrm{s} / 50 \%$, e) $1.5 \mu \mathrm{s} / 60 \%$, f) $2 \mu \mathrm{s} / 66 \%$

kept the same as in the previous experiment. Figure 5 shows that the machining radius was consistent with the increase in the pulse-on time. The processed radius was $642.54 \mu \mathrm{m}$ at $500 \mathrm{~ns}, 656.81 \mu \mathrm{m}$ at $600 \mathrm{~ns}, 644.76 \mu \mathrm{m}$ at $800 \mathrm{~ns}, 638.72 \mu \mathrm{m}$ at $1 \mu \mathrm{s}, 647.77 \mu \mathrm{m}$ at $1.5 \mu \mathrm{s}$, and $656.81 \mu \mathrm{m}$ at $2 \mu \mathrm{s}$.

Figure 6 shows the results after the machining. The machining may occur on the sides of the electrode without the insulation, but the insulated electrode prevents this and makes the machining consistent with a very fine outcome.

\subsection{Surface analysis versus the pulse-on time using insulated and uninsulated electrodes}

Figure 7a shows a SEM image of the Invar film surface after the machining with the uninsulated electrode. The processed area is clearly displayed. Figure $\mathbf{7 b}$ shows the non-contact 3D profile measured. The tapering remained on the side of the Invar film surface after the experiment. Figure 7c shows the results for the pulse-on time of $2 \mu \mathrm{s}$, which allowed the best machinability with both types of electrode. Figure $\mathbf{8}$ shows the equivalent results obtained with the insulated electrode. The voltage in Figure 8c is slightly increased compared to Figure 7c.

With the uninsulated electrode, the processed radius is increased, with almost no influence on the depth. This is attributable to the parts other than the intended machining area with the repeated charging and discharging in the dual layer of electricity because the voltage pulse is exhausted on the other sides of the uninsulated electrode. However, with the insulated electrode, the voltage is concentrated only in the machining area, so the radius is consistently maintained and the machining depth increases. Figures $\mathbf{7 c}$ and $\mathbf{8 c}$ show that the voltage permitted during the actual machining is lower with the uninsulated electrode than with the insulated one. 


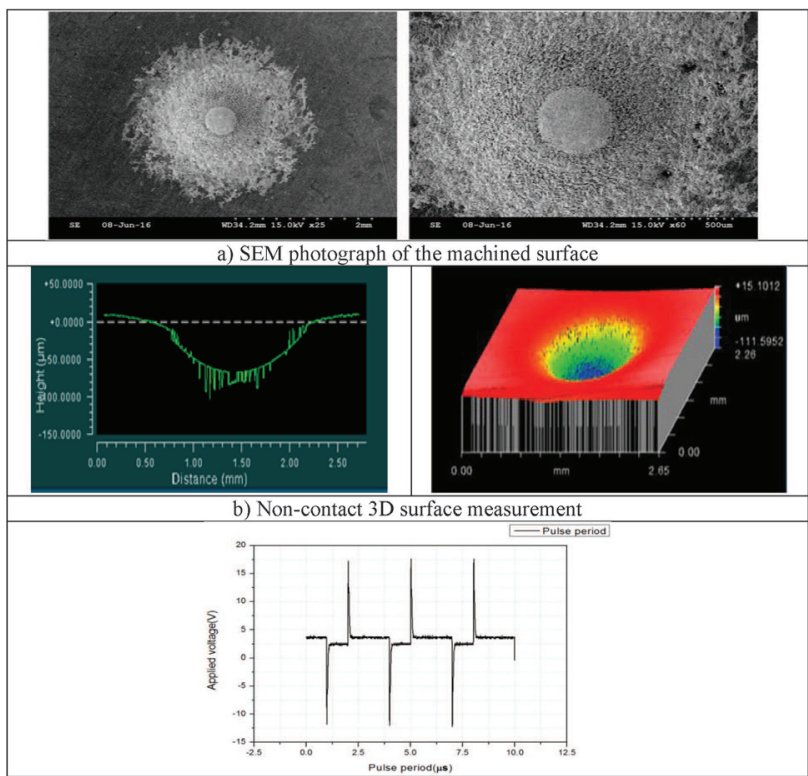

Figure 7: SEM images and non-contact 3D profiles of crater-shaped patterns at different pulse-on times using the uninsulated electrode

\section{CONCLUSIONS}

This study demonstrated that MPECM has suitable process characteristics for machining Invar-alloy surfaces. The machined shape and surface qualities, such as the surface condition and the machining defect, were observed. The important factors influencing the holeshape quality of the Invar alloy are the pulse-on time, the duty factor, the shape of the cathode and the electrolytic process parameters. During the application of MPECM to a fine sheet metal, the electrochemical machining characteristics of the surface of the alloy were revealed and analyzed with respect to different electrode shapes, pulse-on times and applied voltages.

When the uninsulated electrode was used, the machining speed differed depending on the area of the tool electrode that was submerged in the liquid. With a greater machining depth, the machining speed was reduced and there was almost no machining after reaching a certain limit. This is attributable to the current being exhausted because of the repeated charging and discharging in the dual layer of electricity by the pulse, for any part other than the intended machining part.

The insulated electrode prevents the permitted voltage from being exhausted and improves the machinability with the increasing machining depth. In addition, since the voltage flows only into the machining area, a taper does not occur since the sides of the electrode are well insulated. Accordingly, if insulated electrodes are used, it is possible to increase the precision of the form and the processing depth.

This study indicates that the electrode shape and suitable MPECM conditions affect the machinability, and that there is a close interrelation between the electric field on the Invar-alloy surface and the polishing rate. A comparison of the insulated and uninsulated electrodes

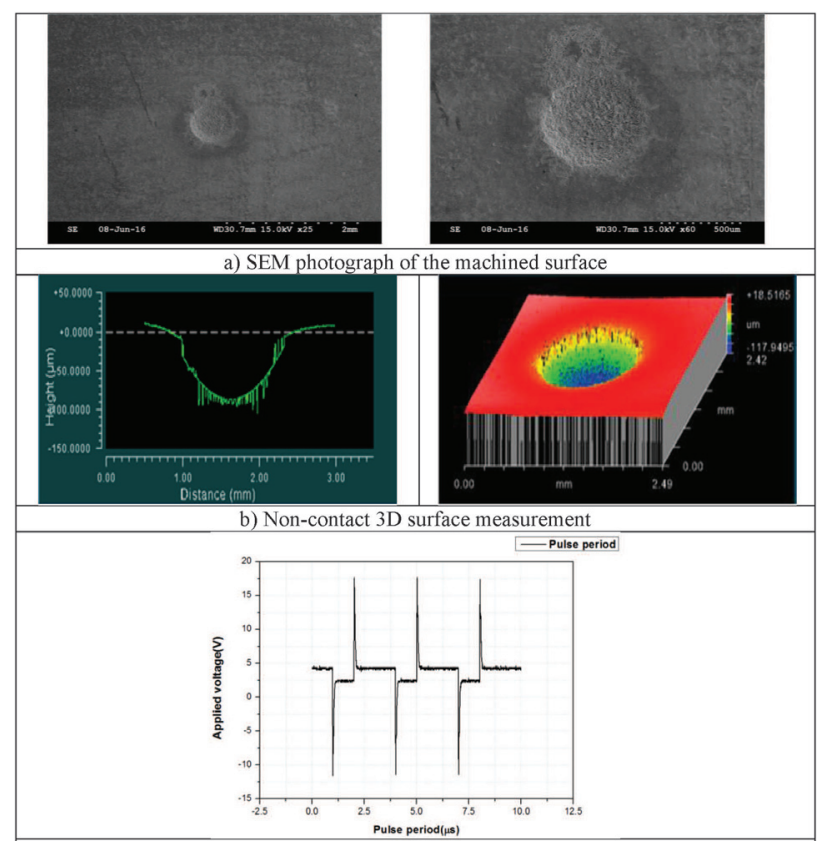

Figure 8: SEM images and non-contact 3D profiles of crater-shaped patterns at different pulse-on times using the insulated electrode

was made, and the effect of the pulse-on time on the electrochemical machinability was determined. MPECM can be recommended to practitioners in different fields to improve the conditions for making holes in the Invar alloy.

The electrolyte of sodium nitrite + sodium tartrate + DI water was used and holes with a $\varnothing 1 \mathrm{~mm}$ diameter were made into the $30-\mu \mathrm{m}$-thick Invar alloy. The future work, therefore, can be made when more engineering data has been gathered. In addition, more research needs to be done on the related factors, such as the surface roughness and the shape accuracy, using controlled micro-pulses.

\section{Acknowledgment}

This work was supported by the Inha University Research Foundation, Korea.

\section{REFERENCES}

${ }^{1}$ D. Grimmentt, M. Schwartz, K. Node, A comparison of DC and pulsed Fe-Ni alloy deposits, Journal of The Electrochemical Society, 140 (1993) 4, 973-978, doi:10.1149/1.2056238

${ }^{2}$ A. Stupnik, M. Leisch, Study on the surface topology of vacuum-fired stainless steel by scanning tunnelling microscopy, Vacuum, 81 (2007) 6, 748-751, doi:10.1016/j.vacuum.2005.11.061

${ }^{3}$ L. S. Andrade, S. C. Xavier, R. C. Rocha-Filho, N. Bocchi, S. R. Biaggio, Electropolishing of AISI-304 stainless steel using an oxidizing solution originally used for electrochemical coloration, Electrochimica Acta, 50 (2005) 13, 2623-2627, doi:10.1016/ j.electacta.2004.11.007

${ }^{4}$ Y. N. Hu, H. Zhou, L. P. Liao, H. B. Deng, Surface quality analysis of the electropolishing of cemented carbide, Journal of Materials Processing Technology, 139 (2003) 1-3, 253-256, doi:10.1016/ S0924-0136(03)00230-9 


\section{MATERIALI IN TEHNOLOGIJE/MATERIALS AND TECHNOLOGY (1967-2017) - 50 LET/50 YEARS}

\section{S.-H. KIM et al.: SURFACE CHARACTERISTICS OF INVAR ALLOY ACCORDING TO MICRO-PULSE}

${ }^{5}$ D. Grimmentt, M. Schwartz, K. Node, A Comparison of DC and Pulsed Fe-Ni Alloy Deposits, Journal of The Electrochemical Society, 140 (1993) 4, 973-978, doi:10.1149/1.2056238

${ }^{6} \mathrm{~S}$. Fujimoto, K. Tsujino, T. Shibata, Growth and properties of Cr-rich thick and porous oxide films on Type 304 stainless steel formed by square wave potential pulse polarisation, Electrochimica Acta, 47 (2001) 47, 543-551, doi:10.1016/S0013-4686(01)00782-4

${ }^{7}$ T. Koyano, M. Kunieda, Ultra-Short Pulse ECM Using Electrostatic Induction Feeding Method, Procedia CIRP, 6 (2013), 390-394, doi:10.1016/j.procir.2013.03.066
${ }^{8}$ M. Boxhammer, S. Altmannshofer, Model Predictive Control in Pulsed Electrochemical Machining, Journal of Process Control, 24 (2014) 1, 296-303, doi:10.1016/j.jprocont.2013.11.003

${ }^{9}$ E. Lee, T. Shin, B. Kim, S. Baek, Investigation of short pulse electrochemical machining for groove process on Ni-Ti shape memory alloy, International Journal of Precision Engineering and Manufacturing, 11 (2010) 1, 113-118, doi:10.1007/s12541-010-0014-3 